\title{
Paradigms apart: Black managers in a White man's world
}

\author{
David A.L Coldwell and A.P. Moerdyk \\ National Institute for Personnel Research, Johannesburg
}

Just as, in the West, Calvinism generated a philosophy and value system which is still evident today in the industrialized world 1 - even if its precise connection with Calvinistic doc. trine is forgotten - so Africa has evolved its own philosophy and corresponding world view. ${ }^{2}$ In this paper it is argued that this African philosophy, however amorphous and ill-defined, pervades Black managers' thinking and adversely affects their performance in Western-oriented organizations.

S. Afr. J. Bus. Mgmt. 1981, 12: 70-76

Net soos Calvinisme 'n filosofie en waarde-sisteem in die Weste tot stand gebring het ${ }^{1}$ - selfs al is die presiese verband met Calvinistiese leerstellinge reeds vergete het Afrika sy eie filosofie en ooreenstemmende wêreldsiening. ${ }^{2}$ In dié referaat word die stelling gemaak dat hierdie Afrika-filosofie, hoewel vormloos en swak gedefinieer, die Swart bestuurder se denke oorheers en 'n nadelige uitwerking het op sy werkverrigting in Westers-georienteerde organisasies.

S.-Afr. Tydskr. Bedryfsl. 1981, 12: 70-76

\section{Paradigms apart: Black managers in a White man's world}

In looking at management practices currently in use in South Africa, it is clear that these are essentially AngloAmerican in orientation and that Black management in this country has had to adapt to an imported industrial system. This stands in direct contrast with the situation of Chinese and Japanese management systems, for example, where the Western industrial system has been adapted to meet the cultural needs of the local peoples. ${ }^{3}$ While many Black managers in South Africa may not disagree formally with the validity of the Western system of management, their fundamentally different cultural paradigms will be likely to result in a mismatch between individual and organizational characteristics and will thus tend to affect the level of efficiency at which they operate.

This paper, therefore, sets out to discuss the question of this mismatch and to assess

- the extent to which African cultural paradigms pervade Black managerial notions regarding specific management processes;

- the extent to which Black managers can be expected to experience 'paradigm conflict' arising from differences between traditional African cultural paradigms and modern Western managerial techniques;

- the extent to which 'paradigm conflict' is likely to affect Black managerial effectiveness.

The paper takes the following form: the first section briefly outlines the source of 'world view' by building up a tentative model. The second section describes some of the main differences between African and Western world views and indicates similarities between African and Chinese world views. The third section deals with the effects non-Western (e.g. Chinese) world views have on management processes. Finally, the last section describes postulated effects of the African world view on Black managerial effectiveness and is followed by the conclusion.

\section{A model of the source of 'world view' and cultural} paradigms

Using Popper's notion of three worlds, the source of the 'world view' is illustrated in Figure 1.

According to Popper ${ }^{4}$ everything in existence and ex- 
perience can be recorded in one or other of three worlds:

- World 1, the world of physical objects and states, consists of inorganic matter, energy, etc.; biological structures and systems, artefacts, tools, books, music, etc.

- World 2 is the world of subjective experience of knowledge, perception, dreams, thoughts, emotions, etc.

- World 3 is the world of man-made culture, comprising the whole of objective knowledge; philosophical, theological, scientific, historical, literary, artistic and technological and including theoretical systems such as scientific problems and critical arguments.

Figure 1 indicates the manner in which Worlds 1 and 3 give information to World 2 and shows that while World 2 interacts with both Worlds 2 and 3, Worlds 1 and 3 are, however, not able to interact directly with each other; there have to be conscious beings to absorb the existing information of these two worlds and to give feed-back. As Popper and Eccles", p.359 put it: 'When the objective knowledge of World 3 (the man-made world of culture) is encoded on various objects of World 1 - books, pictures, structures, machines - it can be consciously perceived only when projected to the brain by the appropriate receptor organs and afferent pathways. Reciprocally the World 2 of conscious experience can bring about changes in World 1 , in the first place in the brain, then in muscular contractions, World 2 in that way being able to act extensively on World 1'.

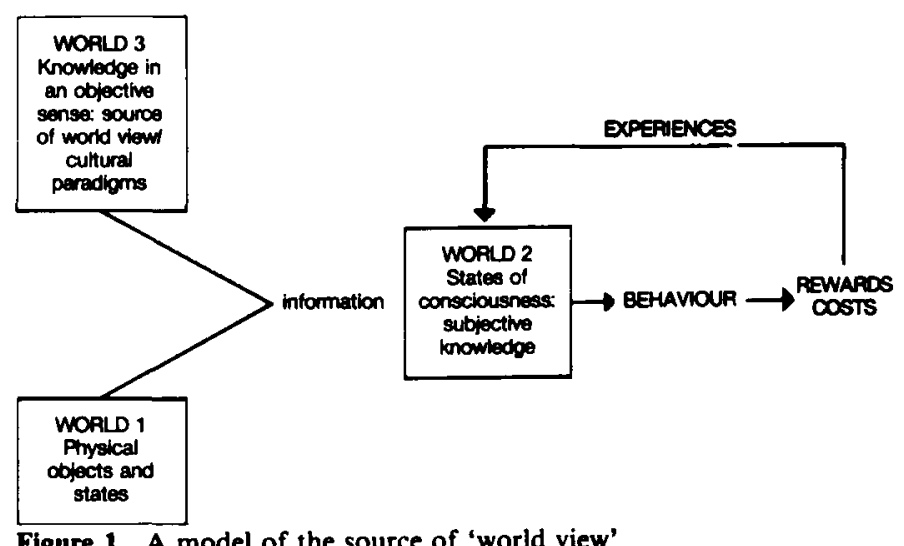

Figure 1 A model of the source of 'world view'

The conscious being behaves in certain ways according to the physical objects which confront him, his objective knowledge and his subjective knowledge gained through his life experiences. His behaviour adjusts not only from a growth in objective knowledge or change in physical situation but also from the reward-cost outcomes of his experiences of the world, which build, layer upon layer, to form the basis of his new (subjective) knowledge of the world. This process is identical to the Piagetian notions of assimilation and accommodation.

It thus follows that the origins of a world view and its corresponding cultural paradigms are located in World 3 and are passed on from one generation to another by the processes of socialization.

Having briefly indicated the source of 'world view', it is now time to describe in some detail differences between
African and Western world views and cultural paradigms - the object of the following section.

Differences between African and Western world views and cultural paradigms

In looking at the differences between African and Western world views, we will follow and add to the points made by Redding. ${ }^{3}$ Of course, it may be argued that what follows is merely a set of abstractions and generalizations that is of academic relevance to anthropologists and other academics but has little relevance for the practicing business manager today. It could also be argued that an overwhelming proportion of Black managers in South Africa are urbanized and have been for a generation or longer, and that even if the question of 'world views' is important, this is only the case with the rural traditional peoples and is of no relevance to the modern, urbanized and Westernized population from which South African managers are drawn. The purpose of this paper is to answer the first objection by showing the practical and economic relevance of this cultural mismatch to Industry and Commerce. In response to the second objection (that it does not have relevance for modernized South African Blacks) we quote from Van den Berg ${ }^{6}$ who writes: 'The question may well be raised as to whether after decades of Christianization, industrialization and urbanization there remains much of anything that can be called traditional Black culture and whether that which is found today is not in fact a transitional culture displaying many grades of enculturation. . . . There are a host of customs and usages that undoubtedly change in a process of enculturation, but there are also many deep rooted beliefs, customs and traditions, of which the upbringing of youth is one, that resist change and are often strengthened in adversity. Henderson and Washington (1975) have shown, for instance, that some aspects of the original African culture may still be recognized in the American Negro's way of life to the present day (p.356)'.

Thus we believe it is important to look at the cultural differences, of which Redding ${ }^{3}$ lists the following: causation, probability, time, self, and morality. In the ensuing discussion we will look in some detail at the African system of beliefs and we will see that while the African and Chinese world views are similar, they both differ markedly from the Western world view.

\section{Causation}

The Western notion of causation stems from the world view of the ancient Greeks and can be contrasted with the world views of Africa and China: 'On the Greek world view, if a particle of matter occupied a particular place at a particular time, it was because another particle had pushed it there. On the other view, the particle's behaviour was governed by the fact that it was taking its place in a "field of force" alongside other particles that are similarly responsive: causation here is not "responsive" but "environmental", ,.7, 0.13 To understand the African notion of causation it is necessary to outline their ontology. African ontology consists of a hierarchy based on the amount of 'vital force' which each tier in the hierarchy possesses. At the apex of the hierarchy is God who is seen as 'the ultimate explanation of genesis and sustenance of both man and all things' 8. p.15 Next come the Spirits 'be- 
ing made up of Superhuman beings and the spirits of men who died a long time ago', 8. p.15 followed by living human beings including those about to be born, then by animals and plants, the remainder of biological life, and finally, by phenomena and physical objects without biological life. From God downward everything in the world has a particular place. All things are found in relationship according to the laws of the ontological hierarchy '... which nothing can break up or destroy. To destroy or remove one of these categories is to destroy the whole existence including the destruction of the Creator, which is impossible. One mode of existence presupposes all the others and a balance must be maintained so that these modes neither drift too far apart from one another nor get too close to one another'. 8, p.16

Causation occurs in accordance with the ontological hierarchy and in agreement with 'certain metaphysical universal immutable and stable laws'. 2, p.67 There are, according to Tempels, ${ }^{2}$ three such laws. Firstly, that man living or dead can 'directly reinforce or diminish the being of another man'.2. p.67 Secondly, that man's ‘. . . vital force can directly influence inferior force beings (animal, vegetable, or mineral) in their being itself'. ${ }^{2, ~ p .69}$ Finally, that 'A rational being (spirit, or living) can act indirectly upon another rational being by communicating his vital influence to an inferior force (animal, vegetable, or mineral) through the intermediacy of which it influences the rational being. This influence will also have the character of a necessarily effective action, save only when the object is inherently the stronger force, or is reinforced by the influence of some third party, or pervades himself by resource to inferior forces exceeding those which his enemy is employing'.2. p.69

Therefore, the African conception of causality is one of a rigidly pre-determined and fixed universe in which only certain phenomena are possible causes of certain other phenomena. The idea, for instance, that germs cause disease in man runs against the hierarchial nature of vital forces and is therefore inconceivable. In terms of the laws of causation outlined above, it is not possible for an inferior vital force (a germ) to cause illness in a superior vital force (man) for such would constitute a contravention of the most fundamental ontological laws. Thus, illness is attributed to the malevolence of other beings, living of dead, and, in particular, to ancestral spirits.

\section{Probability}

Redding ${ }^{3,0.123}$, contrasting Western and Chinese notions of probability, writes: 'The logical sequential thoughtprocess of the Western mind should lend itself naturally to extending into future prediction by extrapolation. In other words, to some degree the future can be "calculated". The Chinese mind might well take a more "fatalistic" view of the future and, consequently, be less prone to fine calculation'. This fatalistic view of the future which characterizes Chinese cognition is similar to the African view. Traditionally, the concept of time is virtually absent in the African world view and the concept of probability is totally absent. Events are either certain to occur in which case they constitute potential time or have taken place, in which case they are actual time. ${ }^{8}$ Thus, Africans could be said to have a 'fatalistic' view of the future - events are either certain and predictable or do not exist until they have been experienced; the 'intermediate' probability view does not exist for them.

\section{Time}

In a word, the Western view of time can be described as 'linear'. As Redding ${ }^{3 .}$. 133 puts it: 'If you ask a Westerner to say how he sees time he will usually talk of a straight line, coming out of, and going into, infinity. More precisely he sees the continuum as being divisible into portions which can be subjected to precise measurement. He has, in the event, an accurate time-sense and out of this come concepts such as punctuality, scheduling and deadlines'. The Chinese view of time, on the other hand, is cyclical and associated with specific events; "Absolute time was hardly touched upon in Chinese philosophy. With Chinese philosophers, time has always been associated with events. In Buddhism, since events are illusory, time is illusory. As such it moves on but will come to an end in Nirvana. In Taoism, time travels in a circle, since a thing comes from a non-being and returns to a non-being'.9. p.135

The African view of time is similar to the Chinese time is viewed in terms of specific events: 'When Africans reckon time, it is for a concrete and specific purpose, in connection with events but not just for the sake of mathematics. Since time is a composition of events, people cannot and do not reckon it in a vacuum . . . The day, the month, the year, one's life time or human history are all divided up or reckoned according to their specific events, for it is these that make them meaningful' ${ }^{8}$, p.19 Mbiti gives a lucid example of what this African conception of time means in practical everyday terms. '... The rising of the sun is an event which is recognized by the whole community, it does not matter, therefore, whether the sun rises at 5 am or 7 am so long as it rises. When a person says that he will meet another at sunrise, it does not matter whether the meeting takes place at 5 am or 7 am so long as it is during the general period of sunrise. Likewise, it does not matter whether people go to bed at $9 \mathrm{pm}$ or 12 midnight: the important thing is the event of going to bed, and it is immaterial whether in one night this takes place at $10 \mathrm{pm}$ while in another it is at midnight. For the people concerned, time is meaningful at the point of the event and not at the mathematical moment.'

\section{Self}

In the Western world view the individual is all. His relationships with others outside his family and close friends are largely instrumental and are based on the realization that in association with others he can accomplish things which he could not as a solitary individual. This view contrasts sharply with the Chinese and African views of self. For the Chinese, a person is considered in terms of his relationships with others and not purely as an individual. ${ }^{10}$ Africans have a similar viewpoint, as Tempels 2, p. 108 points out: 'For the Bantu, man never appears in fact as an isolated individual, as an independent entity. Every man, every individual, forms a link in the chain of vital forces, a living link, active and passive joined from above to the ascending line of his ancestry and sustaining below him the line of his descendants. It may 
be said that among Bantu the individual is necessarily an individual within the clan'.

\section{Morality}

The distinction between Western and Oriental systems of morality is noted by Benedict $11,0.222$ when he writes: "A society that inculcates absolute standards of morality and relies on men's developing a conscience is a guilt culture by definition. . . True shame cultures rely on external sanctions for good behaviour, not, as true guilt cultures do, on an internalized conviction of sin. Shame is a reaction to other people's criticism ... Shame has the same place of authority in Japanese ethics that "a clear conscience", "being right with God", and the avoidance of sin have in Western ethics'.

The African notion of morality could roughly be said to be a combination of Western and Oriental systems because it includes both 'guilt' and 'shame' dimensions. The 'guilt' aspect of the African system of morality is embedded in the ontological hierarchy of forces which we mentioned earlier; 'For men of humble station there is but one way to maintain and increase life, Right and the Good. The way is by the acknowledgement of higher living forces and by the maintenance of their own proper vital rank; or, if they have deviated from it, then by their restoration in dependence on and attachment to the hierarchy of forces'. 2, p.165 Furthermore, 'The individual knows what his moral and legal obligations are and that they are to be honoured on pain of losing his vital force. He knows that to carry out his duty will enhance the quality of his being' 2, p.135

Existing along with this 'guilt' aspect is an equally strong 'shame' view in the African system of morality which is based on a notion of community spirit and interdependence (ubuntu): 'Each is his brothers' keeper. Each has a right and an obligation to expect help from, and give help to his neighbour... Seek the good of community, and you seek your own good. Seek your own good, and you seek your own destruction. Mutual aid is a moral obligation'.12, pp.177-178 These two aspects of African morality are linked to some extent when a specific position in the ontological hierarchy engenders certain responsibilities towards the community: 'The "muntu's" (person's) obligations increase in accordance with his vital rank. The elder, the Chief, the King know very well that their doings do not involve their own personal vital force only. They and their subjects fully realize that their deed will have repercussions upon the whole community subject to them', 3, p.136

Having discussed the Western, Chinese and African world views and differences existing between them, we may now turn our attention to an analysis of the effects contrasting world views have on specific managerial processes. While the discussion in this section will be restricted to contrasting Western and Oriental management approaches, the subsequent section will deal with the postulated effects of the African world view on Black management, for two main reasons. Firstly, because the Western system of management found in South Africa is an imported system, we cannot know with any certainty how South African managerial systems would have developed had the African world view dominated and been able to mould the Western view to meet its own particular cultural specifications. (However, see Onyemelukwe ${ }^{13, p p .123-129}$.) Secondly, since the African world view is quite similar to the Chinese world view, it seems reasonable to assume that, had it been allowed to do so, the African management approach probably would have developed along similar lines.

\section{Effects of contrasting world views on specific management processes}

Redding $^{3 . ~ p .143}$ presents a useful diagram indicating how a particular world view, in this case the Chinese world view, is associated with a specific approach to the basic managerial processes of planning, organizing, leading and control, as illustrated in Figure 2.

Planning presupposes the Western concepts of linear time, causality and probability. Planning becomes a waste of time if, like the Chinese, we hold a fatalistic world view since what happens tomorrow is inevitable and no amount of scheming will change that - what will be, will be. Any short-term managerial planning therefore will tend to be based on hunches and intuition rather than on statistical estimates of probable 'market shares', consumer preferences, etc.

\begin{tabular}{|c|c|c|c|c|c|}
\hline Planning & $\begin{array}{l}\text { Causality } \\
\text { Not formally } \\
\text { developed. }\end{array}$ & $\begin{array}{l}\text { Probability } \\
\text { More use of } \\
\text { nunch and } \\
\text { intuitive, fata. } \\
\text { talistic view. }\end{array}$ & $\begin{array}{c}\text { Time } \\
\text { Low priority } \\
\text { to deadlines. } \\
\text { Non-linearity. }\end{array}$ & Self & Morality \\
\hline Organizing & $\begin{array}{c}\text { Abstract } \\
\text { entities not } \\
\text { separated out. }\end{array}$ & & $\begin{array}{l}\text { Co-ordination } \\
\text { loose. }\end{array}$ & $\begin{array}{l}\text { Personalistic } \\
\text { networks. . }\end{array}$ & \\
\hline Leading & & & & $\begin{array}{c}\text { High subjecti. } \\
\text { vity. Obligation } \\
\text { nets. } \\
\text { Paternatism. }\end{array}$ & $\begin{array}{l}\text { Sensitivity to } \\
\text { face. Pragma- } \\
\text { tism in busi- } \\
\text { ness ethics. }\end{array}$ \\
\hline Control & $\begin{array}{l}\text { 'Control cycle' } \\
\text { not perceived. }\end{array}$ & & $\begin{array}{l}\text { Problems of } \\
\text { urgency and } \\
\text { common } \\
\text { perception of } \\
\text { co-ordinating } \\
\text { deadlines. }\end{array}$ & $\begin{array}{l}\text { Objective } \\
\text { performance } \\
\text { measures not } \\
\text { used. }\end{array}$ & $\begin{array}{l}\text { Use of shame } \\
\text { mechanism. }\end{array}$ \\
\hline
\end{tabular}


Planning also implies the idea of linear time. For instance, MBO systems include objectives for each manager with specific dates set for their completion. Such objective-setting becomes difficult without a linear conception of time. The Chinese, as we have seen, adopt a non-linear view of time and attach low priority to deadlines and time schedules thus making MBO systems largely irrelevant.

Finally, planning involves the Western notion of causality. If planning is to be worthwhile, phenomena must be manipulatable and not conform to a specific, rigidly predetermined behavioural code. In other words, planning only becomes meaningful if, when we plan a certain course of action, we can expect a specific result from that action. And, if we plan a different course we can expect a different result - thus, specific outcomes are not predetermined but are causally related to our purposive planned actions.

Organizing people using impartial criteria with a view to enhancing the bureaucratic efficiency of a firm, is another aspect of the Western managerial system which contrasts sharply with, for example, the Chinese world view and managerial approach. Furthermore, the Chinese manager is unable to devise highly sophisticated organizational structures because of his tendency to shy away from most forms of abstract thinking: 'If the Chinese businessman, in making sensing (sic) of the world does not seize upon abstracts, then the conception of the constructs used in Western bureaucracies will not take place. Certainly Chinese business displays almost none of them in practice and remains reliant on interpersonal relationships for control and co-ordination. High centralization of decision-making is another factor which reflects this and the lack of controlled delegation may here reflect the difference in mental maps'. ${ }^{3 .}$ p.145

Leading: Western ideals of fairness and objectivity in leadership are far removed from the oriental managers' tacit acceptance of favouritism in their assessments of their subordinates' performance which are based largely on the estimated indebtedness for particular services they (the subordinates) may have rendered them. To bolster his leadership position and to punish those who step out of line, the Chinese manager uses the complex and highly sensitive sanction of 'loss of face' when dealing with his subordinates. While a leader himself must take care not to 'lose face' in front of subordinates, he can use the mechanism to maintain discipline and control in their ranks.

Control systems devised by Western managers to ensure the smooth running of complex bureaucracies demand the use of abstract linear logic expressed in Western notions of causality and time. Western managerial control systems are only feasible where jobs are done according to strict time schedules and deadlines. And, where particular control mechanisms can be designed to produce specific results with a predictable degree of success.

The Chinese who, as we have already seen, hold a markedly different view of 'causality', 'time', and 'self' from their Western counterparts, tend to control their organizations without resorting to these Western-style abstractions. This generally means that their organizations are restricted in size so that management is able to retain a strong centralized control over their subor- dinates. In short, control tends to be personalistic; 'The overall flavour is one of Gemeinschaft rather than Gesellschaft relationships, . . . As such it is characterized especially by informality and a lack of what the Westerner sees as rationality and objectivity. It is the opposite of the bureaucracy as defined by Weber'. ${ }^{3, p .139}$

\section{The African world view and Black managerial offec. tiveness}

In South Africa the imported Western world view and in. dustrial system is imposed on the indigenous African world view and generates the kind of problems noted by Tempels. 2, p.31 "And so the African learns from us to read and write, to calculate and to do accounts. He becomes familiar with our techniques; but just like his brother who has stayed in the village, he feels through day to day experience that the lack of comprehension of the Whites prevents the motivations of his conduct from being understood'. Similarly, Onyemelukwe ${ }^{13, p .57}$ distinguishes between form and substance in describing the superficiality of the African adoption of Western cultural paradigms: 'Much of what they do at home, at work and during their leisure is an attempt to copy either what the former colonial masters did or what they observed being done in the advanced countries. Due to no fault of their own, they observe the form but often do not grasp the substance. Hence in carrying out the motions at work, as well as outside working hours, many do not really have an inner feeling for what they are doing'. The significance of this for management is noted by Onyeme-

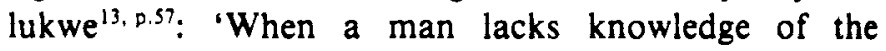
substance of a post he is occupying he is not likely to be enthusiastic or to impart enthusiasm to others, nor is he well able to grasp the essentials of his responsibility'. In short, many Black managers pay lip service to Western managerial values without the kind of commitment necessary to be really effective.

These two general observations written some 14 years apart serve to highlight the fact that although the problem is an old one, it is as important today as it ever was. At a more specific level evidence is plentiful and can be considered as reflecting the deep polarization of basic African paradigms and the Western world view.

Empirical examples of the way specific African cultural paradigms cause conflict in the industrial situation are plentiful. The importance of ontological recognition in a company's promotion policy is indicated by Onyemelukwe ${ }^{13, p .99}$ when he writes: 'One worker complained that, "they (management) don't base it on the years a worker has served. They just give it to anybody they like". Another said, "sometimes workers are collected from outside and given better positions disregarding the older workers"'.

The effects of ignoring ontological status are described by Coldwell $14, p .204$ when he records Black workers' responses to questions concerning supervisory practices: . . . 50\% of the workers indicated bad treatment by supervisors. By this they meant being shouted at, abused and treated like tools rather than real people. The following responses give lucid examples of typical replies: "A supervisor who treats workers as tools and not people no sympathy for the workers" and "A supervisor who fails to co-operate with his subordinates, treats people 
like tools and disregards their feelings".'

It is true that most workers react unfavourably to being treated as mere cogs in a machine - this is the essence of Marx's concept of alienation which he used to describe the Western worker's situation. However, there is little doubt that Black workers are particularly distressed by the dehumanization of their being in Western style organizations since, as Tempels ${ }^{2, p .178}$ puts it, 'what they want more than anything else is not improvement of their economic or material circumstances, but recognition of and respect for their full value as men by Whites'. Today, however, there is little doubt that economic advancement is high on the list of Blacks' priorities.

McKay, ${ }^{13, p .38}$ in her study of upwardly mobile Black managers, records one Black's response to a question concerning upward communication which brings out the essential importance of ontological recognition clearly: 'We have a warm relationship; free to discuss personal problems because I get the feeling that they are interested in the totality of my being' (emphasis added).

One final ontological example will suffice. Something that never fails to produce an angry reaction from Blacks is the norm among Whites in South Africa to refer to adult Black male workers collectively as 'boys'. A seemingly trivial issue when viewed inside the context of Western culture, this insulting term takes on a new, more serious, significance when seen from a Black's perspective. When a White refers to a Black as 'boy' or shows little respect for his age, his rightful position in the ontological hierarchy is being ignored which not only hurts his pride but also undermines the very core of his cultural beliefs.

The distinct concept of time among Africans which constitutes a constant source of frustration for Westernstyle management systems is well-known. Concluding from his empirical investigation, Onyemelukwe ${ }^{13, p .124}$ writes: 'The enjoyment of work for the African is not in the accomplishment of the task alone but also in the manner in which it is done. There is therefore a reaction amounting to almost complete rebellion to schemes which eliminate a slow leisurely work arrangement'.

Empirical examples of 'ubuntu' or community spirit abound; McKay ${ }^{13, p p .21,22}$, for example, records some comments by Blacks from her study which lucidly illustrate the importance they attach to the cultural paradigm:" "Blacks must be accepted and allowed to participate, made to feel part of the system, not just tools to be used" and "Blacks have to be made to feel part of the organization, not just verbally, but practically by sharing benefits; made to feel the company belongs to all . ..".' These comments reflect the essence of 'ubuntu' which can be described as humanity and the sharing of resources.

Conflict between 'ubuntu' and Western perspectives is emphasized in the following comments also recorded in McKay's ${ }^{15}$, p.19 investigation: 'People are not machines to produce only; production-oriented (Whites) people forget important aspects like human relations and social upliftment "welfare of people; there is a mad rush for productivity - always say S.A. is lagging behind, we should just produce continually; nothing wrong with it until placed above human value; over-emphasis to the detriment of the human element; good, but it must be productivity with a human face. Western way often clashes with Blacks' view of work because of their communalism which emphasizes the group over achievement".'

Nepotism and paternalism tend to be the norm among Black South African managers running their own businesses. For example, Mokoatle ${ }^{16, p .238}$ notes: ‘ . . . the tendency among South African Black entrepreneurs is to avoid delegation of authority to an unrelated manager'. Similarly, the Black worker expects nepotistic and paternalistic treatment from management: 'He expects fair treatment in distribution of rewards, especially when he feels he has no relatives or clansmen in top management. He presumes on the other hand, that if his boss is from his own tribe he should get many advantages. He also believes that when his boss is not from his own area he is unlikely to get what is due to him'. ${ }^{13 .}$. .121

The conflict between African nepotism and the Western ideal of bureaucratic impartiality has been well documented by Fallers ${ }^{17}$ and needs no further elaboration. Suffice it to say that typical Western bureaucratic hierarchies contrast sharply with traditional African notions of legitimate authority, and, where these differences are ignored, tend to reduce the effectiveness of Black managers and workers alike.

\section{Conclusion}

Blacks in general, and Black managers in particular, are confronted by a dilemma caused by two contrasting world views existing together. While on the one hand most of them believe in 'ubuntu' and the importance of being part of a community, on the other hand many feel that the materialistic competitiveness and self-assertive individualism which characterizes Western society is unavoidable if Blacks wish to progress inside the present social system. It is postulated that this constant struggle between dissonant cultural paradigms that goes on in the minds of many Blacks, has a deleterious affect on Black managerial performance and is a major source of stress.

Unless Blacks accept Western cultural paradigms more fully, it seems likely that there will remain in them a certain amount of holding back from, lack of involvement in, and general rejection of Western bureaucratic organizations. However, a complete abandonment by Blacks of their own cultural paradigms seems highly unlikely, certainly within the foreseeable future, for two main reasons. Firstly, there has been and continues to be a resurgence of pride in African values and world view (Wilsworth ${ }^{18}$; McKay ${ }^{15}$ ). Secondly, 'ubuntu' pervades the African social structure and socialization process and because of its importance as a mechanism of survival for large sections of the Black South African population, it is likely to be needed for some time to come. Thus, the need to consider culturally appropriate management structures that will allow the economic aims of Western business enterprises to be met from within the Blacks' own cultural paradigm becomes urgent. And, as Onyemelukwe ${ }^{13, \text { p. } 123}$ puts it: 'A new concept of business is required which will take account of the traditions and culture of the African worker. This we call the community concept'. Just how this can be done forms the basis of another publication. 


\section{References}

1. WEBER, M. The Protestant Ethic and the Spirit of Capitalism. George Allen \& Unwin, London, 1980.

2. TEMPELS, P. Bantu Philosophy. Présence Africaine, Paris, 1959.

3. REDDING, S.G. Cognition as an Aspect of Culture and its Relation to Management Processes: An Exploratory View of the Chinese Case. J. Mngmt. Stud., 1980, 17, p. 127.

4. POPPER, K.R. Objective Knowledge: An Evolutionary Approach. Clarendon Press, Oxford, 1972.

5. POPPER, K.R. \& ECCLES, J.C. The Self and its Brain. Springer International, Berlin, 1977.

6. VAN DEN BERG, D.J. Black Education - A New Perspective on Developing the Potentialities of the Black Pupil. Humanitas, 1980, 6(2), p. 97.

7. NEEDHAM, J. The Shorter Science and Civilization in China. Cambridge University Press, Cambridge, 1978.

8. MBITI, J.S. African Religions and Philosophy. Heinemann, London, 1969.

9. CHAN, W.T. 'Synthesis in Chinese Metaphysics' in MOORE, C.A. (Ed) The Chinese Mind. University Press of Hawaii, Honolulu, 1967.

10. HSU, F.L.K. Psychosocial Homeostasis and Jen: Conceptual Tools for Advancing Psychological Anthropology. Am. Anthropol., 1971, 73, p. 23.
11. BENEDICT, R. The Chrysanthemum and the Sword. Meridan, New York, 1946

12. OGUAH, B.E. 'African and Western Philosophy: A Comparative Study' in WRIGHT, R.A. (Ed) African Philosophy. University Press of America, Washington, 1979.

13. ONYEMELUKWE, C.C. Men and Management in Contemporary Africa. Longman, London, 1973.

14. COLDWELL, D.A.L. Role Conflict and Job Satisfaction in Black Industrial Workers: An Investigation of the Validity and Interrelation of these Constructs by the Causal Inference Technique and a Phenomenological Approach. Unpublished Ph.D. thesis, University of South Africa, Pretoria, 1979.

15. McKAY, M. Aspects of Upward Occupational Movement of Blacks. Part II: Experiences of a Group of Upwardly Mobile Black Managers. N.I.P.R. Special Report PERS 313, CSIR, Johannesburg, 1980.

16. MOKOATLE, B.N. 'The Black Entrepreneur in South Africa: A Product of Social Change' in MARAIS, G. \& VAN DER KOOY, R. (Eds) South Africa's Urban Blacks: Problems and Challenges. University of South Africa, Pretoria, 1980.

17. FALLERS, L.A. Bantu Bureaucracy. The University of Chicago Press, Chicago, 1965.

18. WILSWORTH, M.J. Strategies for Survival: Transcending the Culture of Poverty in a Black South African Township. Occasional Paper No. 24, Institute of Social and Economic Research, Rhodes University, Grahamstown, 1980. 